\title{
Characterization of Cellobiose Dehydrogenase from a Biotechnologically Important Cerrena unicolor Strain
}

\author{
Justyna Sulej $^{1}$ - Grzegorz Janusz ${ }^{1}$ - Monika Osińska-Jaroszuk ${ }^{1}$ • \\ Patrycja Rachubik $^{1}$ - Andrzej Mazur ${ }^{2}$ - Iwona Komaniecka ${ }^{2}$. \\ Adam Choma $^{2} \cdot$ Jerzy Rogalski $^{1}$
}

Received: 10 March 2015 / Accepted: 12 May 2015 /

Published online: 24 May 2015

(C) The Author(s) 2015. This article is published with open access at Springerlink.com

\begin{abstract}
Cellobiose dehydrogenase (CDH), a secreted flavocytochrome produced by a number of wood-degrading fungi, was detected in the culture supernatant of a biotechnologically important strain of Cerrena unicolor grown in a modified cellulose-based liquid medium. The enzyme was purified as two active fractions: $\mathrm{CuCDH-FAD}$ (flavin domain) (1.51-fold) with recovery of $8.35 \%$ and $\mathrm{CuCDH}$ (flavo-heme enzyme) (21.21-fold) with recovery of $73.41 \%$. As $\mathrm{CDH}$ from other wood-rotting fungi, the intact form of cellobiose dehydrogenase of C. unicolor is a monomeric protein containing one flavin and one heme b with molecular mass $97 \mathrm{kDa}$ and $\mathrm{pI}=4.55$. The enzyme is glycosylated (8.2\%) mainly with mannose and glucosamine residues. Moreover, the cellobiose dehydrogenase gene $c d h 1$ and its corresponding cDNA from the fungus $C$. unicolor were isolated, cloned, and characterized. The 2316-bp full-length $\mathrm{cDNA}$ of $c d h 1$ encoded a mature $\mathrm{CDH}$ protein containing 771 amino acids preceded by a signal peptide consisting of 18 amino acids. Moreover, both active fractions were characterized in terms of kinetics, temperature and $\mathrm{pH}$ optima, and antioxidant properties.
\end{abstract}

Keywords Cellobiose dehydrogenase $\cdot$ Cerrena unicolor $\cdot$ Purification $\cdot$ Gene $\cdot$ Fungi

\section{Introduction}

Fungi form an important group of microorganisms that have beneficial effects on the environment and human life. In forest ecosystems, they are mostly responsible for breakdown of

Grzegorz Janusz

gjanusz@poczta.umcs.lublin.pl

1 Department of Biochemistry, Maria Curie-Skłodowska University, Akademicka 19 St., 20-033 Lublin, Poland

2 Department of Genetics and Microbiology, M. Curie-Skłodowska University, Akademicka 19 St., 20-033 Lublin, Poland 
abundant large biopolymers such as cellulose, hemicellulose, and lignin [1]. White-rot basidiomycetes are a group of fungi comprising from 1600 up to 1700 species characterized by the ability to depolymerize and mineralize lignin using a set of extracellular ligninolytic enzymes and low molecular compounds $[2,3]$. At the same time, in modern biotechnology, filamentous fungi are major sources of bioactive metabolites, including proteins, peptides, glycoproteins, polysaccharides, lipopolysaccharides, phenolic compounds, triterpenoids, lectins, lipids, and their derivatives [4].

Among the many hitherto-characterized fungal species, Cerrena unicolor was described in literature as one of the best laccase producers [5]. Moreover, this species belonging to Aphyllophorales was proved to secrete extracellular manganese peroxidase, versatile peroxidases [6], and xylanase or cellulase when grown on cellulose [7]. This fungus commonly called "mossy maze polypore" may be found on dead northern hardwood tree species as maple, birch, or alder, where it causes white rot [8]. Besides extracellular enzymes, C. unicolor may be a source of polysaccharides [9] or low molecular fractions of secondary metabolites [10], which possess interesting biomedical and bioelectrochemical properties. However, up to date, cellobiose dehydrogenase, which was proven a crucial enzyme in decomposition of both cellulose and lignin, has not been described in cultures of the genus Cerrena.

Cellobiose dehydrogenase (CDH; EC 1.1.99.18; cellobiose [acceptor] 1-oxidoreductase) is a fungal extracellular hemoflavoprotein, which was discovered in 1974 by Westermark and Eriksson in white rot fungi Trametes versicolor [11] and Phanerochaete chrysosporium (Sporotrichum pulverulentum) [12]. CDHs are usually monomeric enzymes that belong to the glucose-methanol-choline (GMC) family together with other sugar oxidoreductases like the catalytically related enzymes glucose oxidase, pyranose dehydrogenase, and pyranose- 2 oxidase [13]. It is composed of two prosthetic groups, a heme type b (ferriprotoporphyrin IX) and a flavin adenine dinucleotide (FAD) [14] connected through a flexible polypeptide linker region enriched in hydroxy amino acids [15]. This enzyme catalyzes the oxidation of the reducing end of cellobiose and higher cellodextrins in vivo, whereas in vitro lactose and other oligosaccharides with $\beta$-1,4-glycosidic linkages are acceptable substrates [16]. The catalytic cycle of $\mathrm{CDH}$ involves oxidation of sugar substrates to corresponding 1,5-lactones using various electron acceptors with concomitant reduction of flavin to $\mathrm{FADH}_{2}$ [17]. Lactones are finally converted to their carboxylic acids, and flavin is reoxidized by the heme group in two single-electron steps reactions [18]. Phylogenetic analysis of all known $c d h$ genes showed division of the enzymes into three distinct classes: class I, representing only basidiomycetous CDHs; class II, exclusively comprising ascomycetous CDHs; and class III, containing so far uncharacterized or actively expressed CDHs [19]. Although the physiological function of this enzyme has not yet been revealed, our current knowledge points to its participation in the degradation and modification of lignocellulose by generating hydroxyl radicals via the Fenton reaction [20]. Recently, an interaction of $\mathrm{CDH}$ with copper-dependent polysaccharide monooxygenases (PMOs) involved in the degradation of cellulose has been proposed [21, 22]. This model for oxidative cellulose degradation may be widespread throughout the fungal kingdom in parallel with the better described hydrolytic cellulase enzyme system [23]. Recent papers have reported successful application of cellobiose dehydrogenase in a large variety of bioprocesses such as biocatalysis, bioremediation, or production of lactobionic acid [24]. The unique catalytic and bioelectrochemical properties of $\mathrm{CDH}$ have been used in biosensors for detection of cellodextrins [25], maltose [26], lactose $[27,28]$, diphenolic compounds [29], and catecholamines [30] in biofuel cells [15, 31] or in biomedical applications [32, 33]. 
Given the widespread biotechnological application of cellobiose dehydrogenase, new sources of this enzyme are being constantly searched. Recently, C. unicolor strain FCL139 has been found to be a producer of laccase, a unique enzyme in many biotechnological applications. Hereby, we successfully attempted to purify and characterize cellobiose dehydrogenase from this strain. Moreover, the corresponding $c d h$ gene and cDNA were sequenced and analyzed.

\section{Materials and Methods}

\section{Microorganism and Culture Conditions}

The white rot fungus C. unicolor was obtained from the culture collection of the Regensburg University and deposited in the fungal collection at the Department of Biochemistry (Maria Curie-Sklodowska University, Poland) under the strain number 139. The fungus was maintained on $4 \%(w / v)$ malt agar plate. To obtain the inocula, pieces of agar plates with the fungus were grown in the Lindenberg and Holm [34] medium in conical flasks for 10 days at $25{ }^{\circ} \mathrm{C}$. Ten-day-old mycelia were homogenized in a disperser homogenizer T18 basic ULTRA-TURR AX (IKA, Staufen, Germany). The fragmented mycelial culture $(10 \% v / v)$ was used as a standard inoculum for further studies.

In order to obtain the high level of $\mathrm{CDH}$, the strain of C. unicolor (FCL139) was grown in submerged culture for 10 days on a cellulose-based medium [35] with authors' modifications. The medium had the following composition (1 1): $5 \mathrm{~g}$ Avicel, $10 \mathrm{~g}\left(\mathrm{NH}_{4}\right)_{2} \mathrm{HPO}_{4}, 1 \mathrm{~g} \mathrm{KH} \mathrm{PO}_{4}$, $0.3 \mathrm{~g} \mathrm{MgSO}_{4} \times 7 \mathrm{H}_{2} \mathrm{O}, 0.08 \mathrm{~g} \mathrm{CaCl}_{2}, 5 \mathrm{mg} \mathrm{ZnSO}_{4} \times 7 \mathrm{H}_{2} \mathrm{O}, 1.5 \mathrm{mg} \mathrm{MnSO}_{4} \times 4 \mathrm{H}_{2} \mathrm{O}, 1.5 \mathrm{mg}$ $\mathrm{CoCl}_{2} \times 6 \mathrm{H}_{2} \mathrm{O}, 5 \mathrm{mg} \mathrm{FeSO}{ }_{4} \times 7 \mathrm{H}_{2} \mathrm{O}, 100 \mathrm{mg}$ yeast extract, and $0.1 \mathrm{mg}$ thiamine. The $\mathrm{pH}$ was adjusted to 6.5 with $5 \mathrm{M} \mathrm{HCl}$. After inoculation, the cultures were incubated at $28{ }^{\circ} \mathrm{C}$ in an incubator shaker Multitron (Infors, Bottmingen, Switzerland) at $120 \mathrm{rpm}$.

\section{Enzyme Purification Procedure}

The culture supernatant (6 1) was collected on day 10 from the cellulose medium after centrifugation $(12,000 \times \mathrm{g}$ for $30 \mathrm{~min})$ on a $6 \mathrm{~K} 15$ (Sigma, Osterode am Harz, Germany). The clear supernatant was concentrated to $300 \mathrm{ml}$ by the Prep/Scale TFF Cartridge PTGC $10 \mathrm{k}$ polyethersulfone (Millipore, Bedford, MA) and used as a source of a crude enzyme. The proteins in the crude preparation were precipitated by the addition of solid ammonium sulfate in the range of 15-85\% saturation. The resulting suspension was collected by centrifugation, and the protein pellet was resolved in $100 \mathrm{ml}$ deionized water and desalted using a preparative chromatography column $(8 \times 30 \mathrm{~cm})$ filled with a Sephadex G-50 carrier. Fractions containing the protein were concentrated and applied to an anion-exchange DEAE-Sepharose (fast flow) column $(2.5 \times 15)$ connected to Econo System (Bio-Rad, Richmond, VA). The column was previously equilibrated with a $50-\mathrm{mM}$ sodium acetate buffer $(\mathrm{pH} 5.0)$, and the proteins bound on the chromatography matrix were eluted using a linear gradient of 0 to $0.5 \mathrm{M} \mathrm{NaCl}$ in the same buffer at a flow rate of $1 \mathrm{ml} / \mathrm{min}$. Fractions containing cellobiose dehydrogenase activity were pooled and concentrated in an Amicon-stirred cell using a polyethersulfone membrane (10 kDa cutoff). In the next step, affinity chromatography was performed. The concentrated protein was loaded onto a lactose-CPG column $(1.5 \times 8 \mathrm{~cm})$ equilibrated with buffer A $(50 \mathrm{mM}$ sodium acetate buffer $(\mathrm{pH} 5.5))$, washed with buffer B $(50 \mathrm{mM}$ sodium acetate buffer 
( $\mathrm{pH} 4.0)$ ), eluted with buffer $\mathrm{C}$ (200 mM sodium acetate buffer ( $\mathrm{pH} 4.0)$ ), and applied $0.7 \mathrm{M}$ ammonium sulfate. The eluent was collected in $0.5 \mathrm{ml}$ portions. Fractions containing CDH activity (obtained from lactose-CPG) were collected, and a chromatofocusing analysis was performed on an Econo-chromatography column (Bio-Rad, Richmond, VA, USA; $130 \mathrm{~cm}$, packed to a bed height of $20 \mathrm{~cm}$ ) with a Polybuffer exchanger PBE 94 equilibrated with $250 \mathrm{ml}$ of $0.025 \mathrm{M}$ imidazole-HCl buffer ( $\mathrm{pH}$ 7.4). Samples from lactose-CPG chromatography showing $\mathrm{CDH}$ activity $(5 \mathrm{ml})$ were injected onto the column, and the enzyme was desorbed by elution with $200 \mathrm{ml}$ Polybuffer $74-\mathrm{HCl}(\mathrm{pH} 3.0)$ at a flow rate of $0.5 \mathrm{ml} / \mathrm{min}$. The active fractions were pooled out, and the purified enzyme solutions were used for kinetic experiments.

\section{Synthesis of Lactose-CPG}

The controlled porous glass (CPG) (Cormay, Lublin, Poland) was prepared according to the method described previously [36]. The support was activated by $\gamma$-aminopropyltriethoxysilane ( $\gamma$-APTES) according to a method that permits a high density of amino groups on the glass surface [37]. The activated support (APTES-CPG) was further used for affinity chromatography by binding the CDH substrate lactose to the activated support according to a method described in detail elsewhere [38]. The resulting sorbent lactose-CPG was used in the affinity chromatography.

\section{Enzyme Assays and Protein Determination}

The activity of cellobiose dehydrogenase was assayed according to Baminger et al. [1] with slight modifications. CDH activity was specifically determined by monitoring the reduction of the electron acceptor 2,6-dichloroindophenol (DCIP) (Sigma Chemical Co., St. Louis, MO, USA) at $520 \mathrm{~nm}\left(\varepsilon_{520}=6.8 \mathrm{mM}^{-1} \mathrm{~cm}^{-1}\right), \mathrm{pH} 4.5$, and $30{ }^{\circ} \mathrm{C}$ using a Shimadzu UV-160A (Shimadzu, Tokyo, Japan) spectrophotometer. The reaction mixture $(1 \mathrm{ml})$ contained $50 \mu \mathrm{l}$ of $3 \mathrm{mM}$ DCIP (solution in water containing $10 \% \mathrm{v} / \mathrm{v}$ ethanol), $100 \mu$ l lactose $(300 \mathrm{mM}$ in $100 \mathrm{mM}$ sodium acetate buffer, $\mathrm{pH} 4.5), 50 \mu \mathrm{NaF}$ ( $80 \mathrm{mM} \mathrm{NaF}$ ) in water, and an appropriate amount of the same buffer. After temperature adjustment, the reaction was started by the addition of an appropriately diluted $\mathrm{CDH}$ sample $(100 \mu \mathrm{l})$ and the decrease in absorbance was monitored during the first $60 \mathrm{~s}$. The final enzyme activity was expressed as nkat per liter.

Alternatively, $\mathrm{CDH}$ activity was selectively determined by following the reduction of $20 \mu \mathrm{M}$ cytochrome c at $\lambda=550 \mathrm{~nm}$ and $30^{\circ} \mathrm{C}$ (Sigma Chemical Co., St. Louis, MO, USA). The reaction was performed in $100 \mathrm{mM}$ sodium acetate buffer, $\mathrm{pH} 4.5$, containing $30 \mathrm{mM}$ lactose and $4 \mathrm{mM} \mathrm{NaF}$. The extinction coefficient $(\varepsilon)$ was $19.6 \mathrm{mM}^{-1} \mathrm{~cm}^{-1}$ [39]. This assay determined the activity of the intact protein containing both the flavin and the heme domains.

The protein concentration was determined using the Bradford method [40] with crystalline bovine serum albumin (BSA) as a standard or by monitoring the ultraviolet (UV) absorbance at $280 \mathrm{~nm}$.

\section{Spectral Characterization}

The spectrum of $\mathrm{CDH}$ purified to homogeneity was recorded from 250 to $650 \mathrm{~nm}$ in both the oxidized and the reduced states using a Shimadzu UV-160A spectrophotometer (Shimadzu, Tokyo, Japan). Purified CDH was diluted in $100 \mathrm{mM}$ sodium acetate buffer, $\mathrm{pH} 4.5$, to an 
absorbance of $\sim 2.5$ at $280 \mathrm{~nm}$, and the spectrum was recorded before and immediately after the addition of an approximately 1000-fold molar excess of lactose to the cuvette. The index of purity (RZ) of the oxidized CDH was calculated as the ratio of the absorbance at $420 \mathrm{~nm}$ to the absorbance at $280 \mathrm{~nm}[19]$.

\section{Effect of Temperature and pH on CDH Activity and Stability}

DCIP and cytochrome $\mathrm{c}$ as electron acceptors and lactose as a substrate were used for assessing the effect of $\mathrm{pH}$ and temperature on the cellobiose dehydrogenase activity and stability. The effect of $\mathrm{pH}$ on enzyme activity was estimated in the range from 2.5 to 8.0 in $0.1 \mathrm{M}$ Mcllvaine's buffer. Dependence of stability on $\mathrm{pH}$ was determined at $30{ }^{\circ} \mathrm{C}$ by incubation in variable $\mathrm{pH}$ ranges ( $\mathrm{pH}$ 2.0-9.0 0.1 M Britton-Robinson buffer) for $12 \mathrm{~h}$ followed by measurement of the residual activities every $30 \mathrm{~min}$.

The optimum temperature of the purified $\mathrm{CDH}$ was determined by performing enzymatic assays at different temperatures $\left(4-80^{\circ} \mathrm{C}\right)$. The thermal stability was investigated by incubating the enzyme solution in a $0.1 \mathrm{M}$ sodium acetate buffer $(\mathrm{pH} 4.5)$ at various temperatures $\left(30-90{ }^{\circ} \mathrm{C}\right)$; aliquots were drawn every $30 \mathrm{~min}$ for $12 \mathrm{~h}$, and their residual enzyme activities were measured. Controls were carried out using the enzyme solutions without preheating, and its activity was taken as $100 \%$.

\section{Determination of Kinetic Constants}

Kinetic constants were determined for various concentrations of $\mathrm{CDH}$ substrates $(0.1$ to $10 \mathrm{mM}$ ) and DCIP and cyt $\mathrm{c}$ as electron acceptors. All measurements were performed in triplicates. The $\mathrm{K}_{\mathrm{m}}$ and $\mathrm{V}_{\max }$ for the purified enzyme were calculated by nonlinear leastsquares regression, fitting the observed data to the Michaelis-Menten equation. The OriginPro 8 software (OriginLab Corporation, Northhampton, MA, USA) was used for data analysis.

\section{Effect of Metal Ions and Potential Inhibitors}

Effects of various metal ions and other reagents on $\mathrm{CDH}$ activity were investigated by adding inorganic salts, imidazole, and SDS (to the final concentration from 0.1 to $100 \mathrm{mM}$ ) to the samples of the enzyme dissolved in $100 \mathrm{mM}$ sodium acetate buffer $(\mathrm{pH} 4.5)$ to the total volume of $1 \mathrm{ml}$. These assays were performed with lactose as a substrate and DCIP as an electron acceptor. Control tests were performed in parallel in the absence of metal ions and inhibitors.

\section{Electrophoresis and Peptide Sequencing by LC-MS/MS}

Sodium dodecylsulfate-polyacrylamide gel electrophoresis (SDS-PAGE) (10\%) was performed as described by Laemmli [41]. Proteins were visualized by silver staining [42] and Coomassie Brilliant Blue G250 using PageRuler Prestained Protein Ladder (Fermentas, Glen Burnie, MA, USA). After the electrophoretic separation of the samples, equal pieces of $2 \times 7 \mathrm{~mm}$ were cut out from the gel lanes. The spectrometric analysis of polypeptides was carried out in the Environmental Laboratory of Mass Spectrometry, Institute of Biochemistry and Biophysics of the Polish Academy of Sciences in Warsaw (Poland). The equipment used was sponsored in part by the Centre for Preclinical Research and Technology (CePT), a project co-sponsored by European Regional Development Fund and Innovative Economy, The National Cohesion Strategy of Poland. The samples were analyzed by HPLC coupled with tandem mass spectrometry (liquid 
chromatography/two stage mass spectrometry - LC-MS/MS) according to Kordan et al. [39]. The output list of precursor and product ions was compared with the protein database of the National Center for Biotechnology (NCBI, USA) using the MASCOT local server.

\section{Analysis of the CDH Carbohydrate Moiety}

For sugar analysis, the $\mathrm{CDH}$ sample was hydrolyzed with $2 \mathrm{M}$ trifluoroacetic acid (TFA) $\left(100{ }^{\circ} \mathrm{C}, 4 \mathrm{~h}\right)$. The liberated monosaccharides were reduced with $\mathrm{NaBD}_{4}$ and converted into alditol acetates [43]. The components were identified on the basis of retention times and mass spectra of authentic standards using the gas chromatography-mass spectroscopy technique. GC-MS was carried out on an Agilent Technologies gas chromatograph (7890A) connected to a mass selective detector (inert XL EI $\backslash$ CI MSD 5975C). The chromatograph was equipped with a capillary column HP-5MS (30 $\mathrm{m} \times 0.25 \mathrm{~mm}$, film thickness $0.25 \mu \mathrm{m}$ ) (Agilent Technologies, Santa Clara, CA, USA). The carrier gas was helium with a flow rate of $0.7 \mathrm{ml} \mathrm{min}{ }^{-1}$. The temperature program was as follows: $150{ }^{\circ} \mathrm{C}$ for $5 \mathrm{~min}$, raised to $310^{\circ} \mathrm{C}$ at $5{ }^{\circ} \mathrm{C} \mathrm{min}{ }^{-1}$, and kept for $10 \mathrm{~min}$. Total carbohydrates were determined by phenol-sulfuric method (Dubois) [44]. A standard curve was prepared to quantify mannose.

\section{Antioxidant Activity Assays}

The antioxidant properties of $C$. unicolor $\mathrm{CDH}$ was investigated in the presence of cellobiose and lactose as the substrates of enzyme as we described previously [45]. The standards (Trolox and vitamin C) well known for their strong antioxidant activity were used as a positive control. All measurements were performed in triplicate.

\section{DPPH Free Radical-Scavenging Test}

The antioxidant activity of cellobiose dehydrogenase was determined using the DPPH equivalent, according to an adapted colorimetric procedure described by Paduch et al. [46] with slight modification. This method is based on the ability of 1,1-diphenyl-2-picrylhydrazyl (DPPH), a stable free radical, to decolorize in the presence of antioxidants. The tested compound $(0.1 \mathrm{ml})$ at concentrations ranging from 6.25 to $800 \mu \mathrm{g} / \mathrm{ml}$ was added to $0.1 \mathrm{ml}$ of DPPH solution $(0.2 \mathrm{mg} / \mathrm{ml}$ in ethanol). The absorbance was measured spectrophotometrically at $515 \mathrm{~nm}$ using a Microplate Reader Elx800 (BioTek, Winooski, VT, USA) after 15 min (the time required to achieve the reaction plateau) of incubation at room temperature.

The capability of scavenging DPPH radicals was calculated by the following formula:

$$
\text { DPPH scavenging effect }(\%)=\left[\left(\mathrm{A}_{0}-\mathrm{A}_{1}\right) / \mathrm{A}_{0}\right] \times 100
$$

where $A_{0}$ means the absorbance of the control sample and $A_{1}$ means the absorbance of the standards or tested compounds.

\section{ABTS Free Radical-Scavenging Test}

The ABTS (2,2'-azinobis (3-ethylbenzothiazoline-6-sulfonic acid) diammonium salt) radicalscavenging ability of cellobiose dehydrogenase was recorded according to the procedure of $\mathrm{Re}$ et al. [47] with some modification. For detection of the antioxidant capacity, $10 \mu \mathrm{L}$ of the 
investigated compounds at concentrations ranging from 6.25 to $800 \mu \mathrm{g} / \mathrm{mL}$ was mixed with $990 \mu \mathrm{L}$ of the ABTS radical solution. The percentage of ABTS oxidation was calculated by the presented formula:

$$
\text { ABTS }^{+} \text {scavenging effect }(\%)=\left[\left(\mathrm{A}_{0}-\mathrm{A}_{1}\right) / \mathrm{A}_{0}\right] \times 100
$$

where $A_{0}$ means the absorbance of the control samples and $A_{1}$ is the absorbance at $734 \mathrm{~nm}$ of the investigated compounds/standards.

The $\mathrm{EC}_{50}$ value, defined as the amount of the antioxidant necessary to decrease the initial DPPH and ABTS concentration by $50 \%$, was calculated from the results. The inhibition curves were prepared, and $\mathrm{EC}_{50}$ values were obtained as described previously [10].

\section{DNA Manipulation Techniques}

Standard techniques for plasmid isolation, agarose gel electrophoresis, and DNA cloning were employed [48]. Automatic sequencing was performed using the BigDye ${ }^{\mathrm{TM}}$ Terminator Cycle Sequencing Kit and an ABI PRISM 310 sequencer or ABI PRISM 3730 XL (Applied Biosystems, Carlsband, CA, USA).

\section{Preparation of Total mRNA, cDNA Synthesis, and Amplification}

Total mRNA and cDNA synthesis and amplification were performed, as described previously [45]. To amplify the CDH 3' cDNA fragment, degenerate primer GSP1 was designed using CDH gene sequences available in GenBank. To amplify complete CDH cDNA, gene-specific primers (GSP) were designed on the basis of an available sequenced CDH 3' cDNA fragment (Table 1).

\section{Genomic DNA Isolation, Amplification, and Cloning of the cdh1 Gene}

DNA from C. unicolor was isolated according to Borges et al. [49], as described previously [45]. To amplify the cellobiose dehydrogenase gene, two pairs of primers genCerCDH (Table 1) were designed on the basis of already sequenced CDH cDNA. All PCR amplifications were carried out using Sigma RedTaq in a Tpersonal thermal cycler (Biometra, Goettingen, Germany). Specific PCR products were purified using the Cleanup kit (A\&A Biotechnology, Gdynia, Poland) and inserted into the pTZ57R/T vector from the InsTAclone kit (Fermentas, Glen Burnie, MA, USA). Clones with target fragments were analyzed by sequencing.

Table 1 Gene-specific primer sequences and annealing temperatures

\begin{tabular}{llc}
\hline Primer & Sequence 5' 3 $^{\prime}$ & Tm $\left[{ }^{\circ} \mathrm{C}\right]$ \\
\hline CerCDHGSP1 & GCCCAGTTWTCWTANGCWTCGAT & $53.5-55.3$ \\
CerCDHGSP2 & CGAAGGGTTGTCCGACACAGCCTGCCC & 67.3 \\
CerCDHGSP3 & TCGACCGACGGCCAGCGCTACCTCG & 67.5 \\
CerCDHGSP4 & GGGAGGTTCGCCGCCGCGGTG & 66.1 \\
genDNA1F & GCCCTGTTTCAGCTCTCC & 52.6 \\
genDNA1R & ACCGAAAGCATGATCTTTGAAGTCCG & 58 \\
genDNA2F & GGTGGACCAAGTACGGCTGAAAAG & 59,1 \\
genDNA2R & ATTGTCGAGATAACATCCTTGAGTGC & 56,4 \\
\hline
\end{tabular}




\section{Nucleotide Sequence Accession Numbers}

The following GenBank accession numbers were given to the $\mathrm{CDH}$ nucleotide sequences determined in this study: KC862284 - C. unicolor strain FCL139 cellobiose dehydrogenase gene $(c d h)$, complete cds; KC862282 - C. unicolor strain FCL139 cellobiose dehydrogenase mRNA $(c d h)$, complete cds.

\section{Bioinformatics Tools}

Nucleic acid sequences were analyzed using Lasergene v.8.0 analysis software (DNASTAR, Inc, Madision, WI, USA). Database searches were performed with the BLAST and FASTA programs at the National Centre for Biotechnology Information (Bethesda, MD, USA) and European Bioinformatics Institute (Hinxton, UK), respectively. Multiple DNA and protein sequence alignments were performed with the Clustal-W algorithm [50]. Phylogenetic tree visualization was performed using the TreeView applet [51]. Glycosylation sites were detected with NetNGlyc v.1.0 (http://www.cbs.dtu.dk/services/NetNGlyc/) and NetOGlyc v.4.0 [52]. Conserved domains were analyzed by CDART [53].

\section{Statistical Analysis}

All presented results are expressed as a mean $\pm \mathrm{SD}$ from three independent experiments $(n=3)$. The mean values as well as standard deviation were calculated by the Excel program (Microsoft Office 2010 package), and only values of $p \leq 0.05$ were considered as statistically significant.

\section{Results and Discussion}

\section{Production and Purification of Cellobiose Dehydrogenase}

Cellobiose dehydrogenase production by C. unicolor strain FLC139 was performed in shaking flasks on the cellulose-based medium. The mycelium was grown for 10 days, and then the culture liquid was collected, concentrated, and used as a source of crude enzyme for further purification steps and other studies. CDH was partially purified by ammonium sulfate precipitation in the range of 15 to $85 \%$ saturation with a purification factor of 2.07 -fold and a recovery of $84.93 \%$ (Table 2). The resulting precipitate was dissolved in $100 \mathrm{ml}$ distilled water and desalted on the Sephadex G-50 column. The protein fractions obtained from ammonium sulfate precipitation were applied to a DEAE-Sepharose chromatographic column. The elution profile from the ion-exchange chromatography on the DEAE-Sepharose column showed the $\mathrm{CDH}$ activity as a single peak, which was purified 28.97 -fold with a yield of $70.34 \%$. The active fractions of cellobiose dehydrogenase were combined, concentrated on the stirred ultrafiltration cell equipped with a $10-\mathrm{kDa}$ cutoff polyethersulfone membrane, and used in the subsequent step of chromatography on the lactose-CPG column. The affinity fractionation (lactose-CPG) gave only one cellobiose dehydrogenase activity peak purified approximately 53 -fold in yields of $59 \%$. The active fractions of cellobiose dehydrogenase were pooled out and further fractionated by chromatofocusing on a Polybuffer exchanger PBE 94. A summary of the purification procedures of the cellobiose dehydrogenase is presented in Table 2. The last purification step (chromatofocusing) resulted in separation of two active fractions: $\mathrm{CuCDH}-$ 
Table 2 Purification of CDH from Cerrena unicolor strain FCL139 culture filtrate

\begin{tabular}{|c|c|c|c|c|c|}
\hline Purification step & $\begin{array}{l}\text { Total protein } \\
(\mathrm{mg})\end{array}$ & $\begin{array}{l}\text { Total activity } \\
\text { (nkat) }\end{array}$ & $\begin{array}{l}\text { Specific activity } \\
\text { (nkat/mg) }\end{array}$ & Yield (\%) & $\begin{array}{l}\text { Purification } \\
\text { fold }\end{array}$ \\
\hline Culture filtrate & 1800.00 & 21180.00 & 11.77 & 100 & 1 \\
\hline Ultrafiltration $(10 \mathrm{kDa})$ & 1275.00 & 20377.50 & 15.98 & 96.21 & 1.36 \\
\hline Precipitation $\left(\mathrm{NH}_{4}\right)_{2} \mathrm{SO}_{4}$ & 737.00 & 17988.00 & 24.41 & 84.93 & 2.07 \\
\hline $\begin{array}{l}\text { DEAE-sepharose } \\
\text { chromatography }\end{array}$ & 43.70 & 14898.48 & 340.93 & 70.34 & 28.97 \\
\hline Lactose-CPG chromatography & 20.30 & 12598.60 & 620.62 & 59.48 & 52.74 \\
\hline $\begin{array}{l}\text { Chromatofocusing PBE-94 } \\
\text { CuCDH-FAD }\end{array}$ & 3.25 & 319.15 & 98.20 & 1.51 & 8.35 \\
\hline Chromatofocusing PBE-94 CuCDH & 5.20 & 4491.50 & 863.75 & 21.21 & 73.41 \\
\hline
\end{tabular}

FAD (a flavin-only fragment of the enzyme), i.e., a very small fraction purified with recovery of $1.5 \%$, and $\mathrm{CuCDH}$ (the intact enzyme) purified with a yield of $21.2 \%$ (73.4-fold). Two $\mathrm{CDH}$ activities were also obtained from fungi Irpex lacteus [54], T. versicolor [55], and Pycnoporus sanguineus [45]; however, Humicola insolens contained three $\mathrm{CDH}$ fractions while $P$. chrysosporium contained only one [56]. In this study, the major fraction of CDH $(\mathrm{CuCDH})$ was used for further investigation as $\mathrm{CDH}$ from $C$. unicolor. The enzyme was purified from the culture supernatant to apparent homogeneity (Fig 1). The high spectral ratio $\mathrm{A}_{420} / \mathrm{A}_{280}$ ( $\mathrm{RZ}$ value) is generally accepted as an indication of the absence of contaminating proteins [57]. The purified intact $\mathrm{CDH}$ from $C$. unicolor showed an $\mathrm{A}_{420} / \mathrm{A}_{280}$ ratio of 0.57 , whereas the flavin fragment has a low RZ value (0.21). Besides the purity factor (RZ), the most important was the ratio of DCIP and cyt c activity (value around 1), which determines the rate of degradation of the intact enzyme on the flavin and heme domains [58]. The factor obtained in this study indicates that the intact $\mathrm{CDH}$ was rather stable in the culture conditions

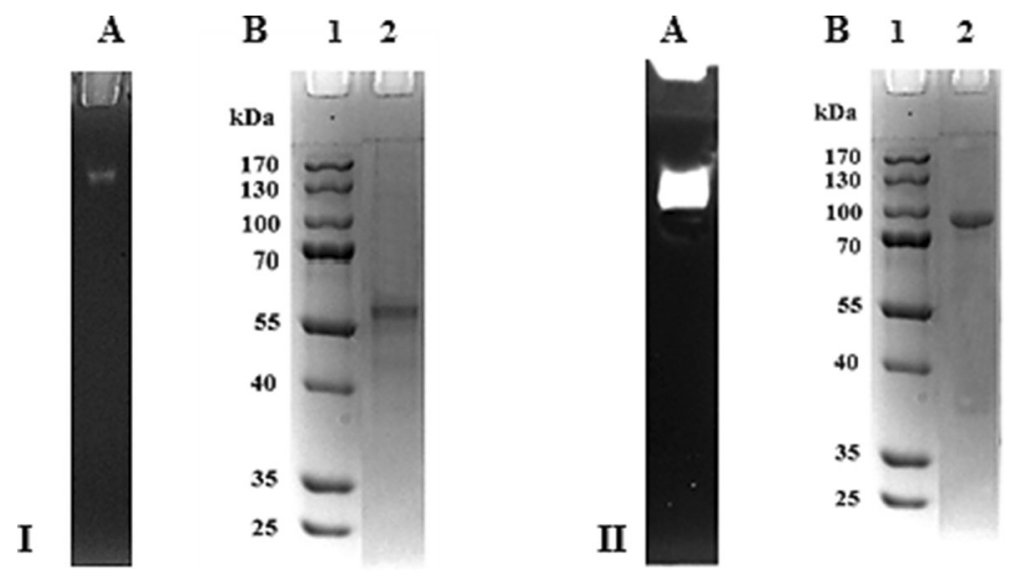

Fig. 1 Activity staining $(A)$ and SDS-PAGE $(B)$ of the purified fractions cellobiose dehydrogenase from Cerrena unicolor: CuCDH-FAD $(I)$ and $\mathrm{CuCDH}(I I)$. PageRulerPrestained Protein Ladder (Fermentas, Glen Burnie, MA, USA) (lane 1), purified CDH (lane 2) 
and during the purification procedure. The proteolytic cleavage to the DCIP active flavin fragment is negligible.

\section{Enzyme Functional Parameters}

The optimum temperature of $\mathrm{CDH}$ was evaluated by measuring the activity of the purified enzyme at different temperatures. The enzyme activity was investigated with lactose as a substrate and two different electron acceptors (DCIP and cyt c). The maximum activity was recorded at $60{ }^{\circ} \mathrm{C}$ for both substances (Fig. 2A). Similar results were obtained for cellobiose dehydrogenase from Ceriporiopsis subvermispora [57]. Thermostability was examined by measurement of the activity over time (Fig. 3a). Complete loss of enzyme activity was recorded at $90{ }^{\circ} \mathrm{C}$ after heat exposure for $30 \mathrm{~min}$ and at $50{ }^{\circ} \mathrm{C}$ after $12 \mathrm{~h}$. The enzyme seemed to be more stable than cellobiose dehydrogenase from Pycnoporus cinnabarinus [59].
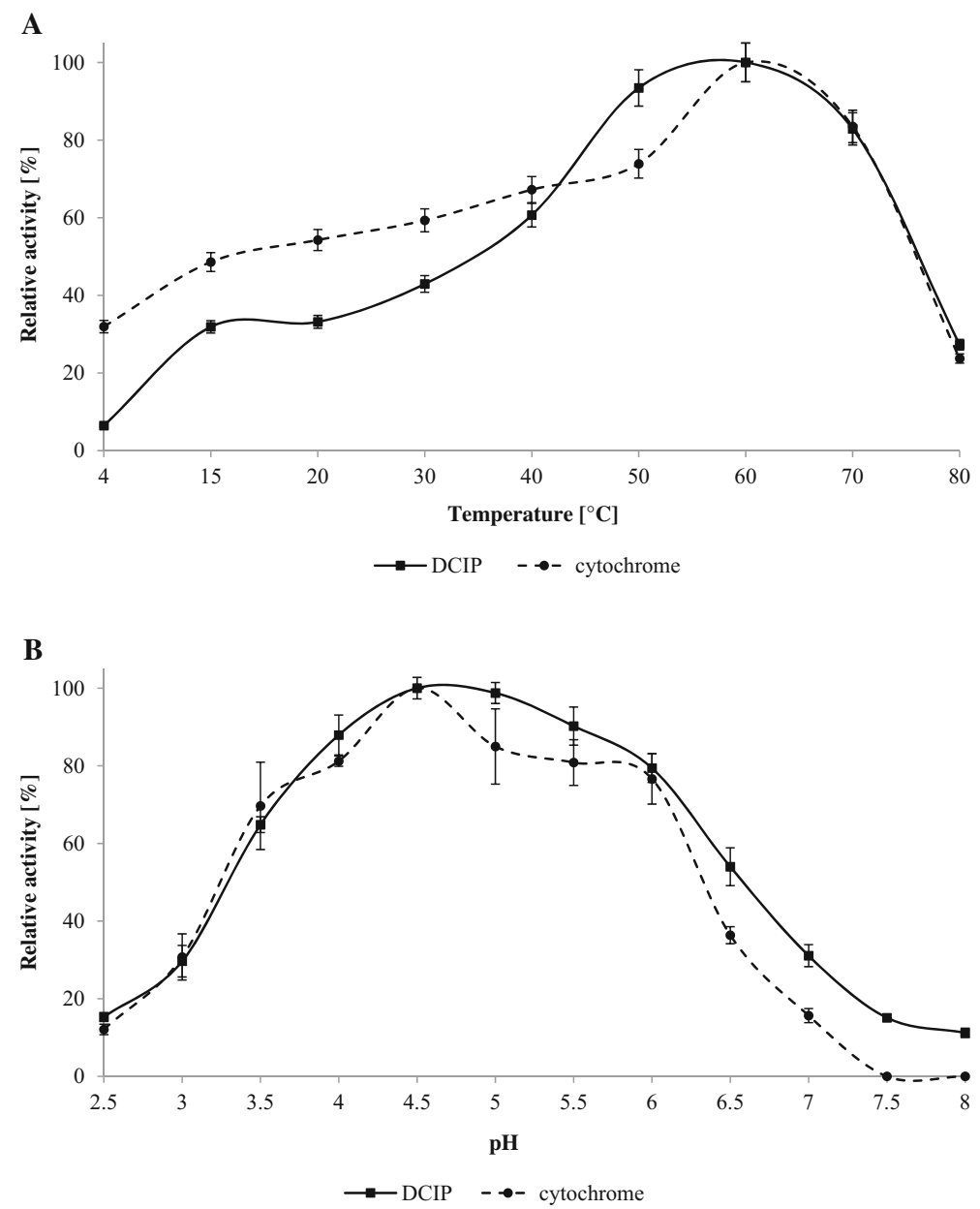

Fig. 2 Effect of temperature (a) and $\mathrm{pH}$ (b) on activity of Cerrena unicolor $\mathrm{CDH}$. Values represent the mean \pm $\mathrm{SD}$ of triplicate samples 

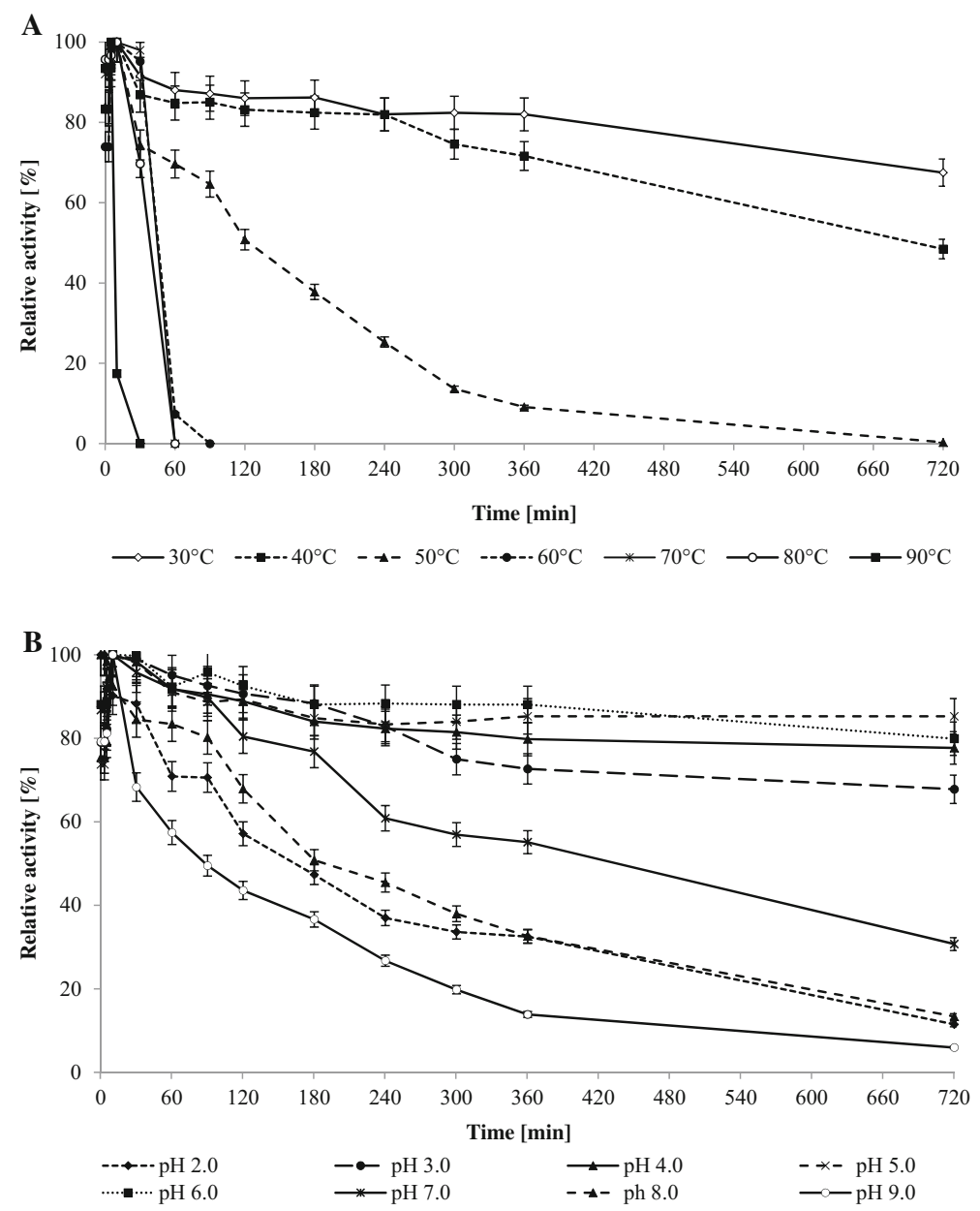

Fig. 3 Thermostability (a) and $\mathrm{pH}$ stability (b) of Cerrena unicolor CDH. Activity was assayed with DCIP as the electron acceptor. Values represent the mean $\pm \mathrm{SD}$ of triplicate samples

The effect of $\mathrm{pH}$ changes on the activity of the purified enzyme from C. unicolor was also investigated using McIlvaine buffer with a $\mathrm{pH}$ range from 2.5 to 8.0. $\mathrm{CDH}$ exhibited maximum activity at pH 4.5 independently from the electron acceptor (Fig. 2B). Cellobiose dehydrogenases from most Basidiomycetes fungi are known to have $\mathrm{pH}$ optima in the acid range as opposed to Ascomycetes showing optimum activity in alkaline conditions [19]. CDHs from different sources are generally stable in a wide range of $\mathrm{pH}$ from 3 to 10 [15]. In this study, the enzyme was stable for $12 \mathrm{~h}$ at $\mathrm{pH} 3-6$, losing $50 \%$ of its initial activity within approximately $3 \mathrm{~h}$ at $\mathrm{pH} 2.0$ and 8.0. CDH was especially sensitive to $\mathrm{pH}$ values above 9.0 (Fig. 3b).

The kinetic parameters of the purified cellobiose dehydrogenase were analyzed with cellobiose, lactose, and glucose as substrates using DCIP and cytochrome c as electron acceptors at $30{ }^{\circ} \mathrm{C}$ (Table 3). The results indicate that cellobiose was the best substrate of $\mathrm{CDH}$ with the catalytic efficiencies with a $\mathrm{k}_{\mathrm{cat}} / \mathrm{K}_{\mathrm{m}}$ value of $66 \mathrm{mM}^{-1} \mathrm{~s}^{-1}$ when DCIP was an electron acceptor and $109 \mathrm{mM}^{-1} \mathrm{~s}^{-1}$ when cytochrome c was used. Lactose was the least preferred substrate, with a $\mathrm{k}_{\mathrm{cat}} / \mathrm{K}_{\mathrm{m}}$ value of 4 and $11 \mathrm{mM}^{-1} \mathrm{~s}^{-1}$ in the presence of DCIP and 
Table 3 Kinetic constants of cellobiose dehydrogenase for carbohydrate substrates

\begin{tabular}{llllllc}
\hline Enzyme & Substrate & Electron acceptor & $\begin{array}{l}\mathrm{Km} \\
{[\mathrm{mM}]}\end{array}$ & $\begin{array}{l}\mathrm{Vmax} \\
{[\mu \mathrm{M} / \mathrm{min}]}\end{array}$ & $\begin{array}{l}\mathrm{kcat} \\
{\left[\mathrm{s}^{-1}\right]}\end{array}$ & $\begin{array}{l}\mathrm{kcat} / \mathrm{Km} \\
{\left[\mathrm{mM}^{-1} \mathrm{~s}^{-1}\right]}\end{array}$ \\
\hline CuCDH-FAD & Cellobiose & DCIP & 0.158 & 0.034 & 4.83 & 30.59 \\
& & Cyt c & - & - & - & - \\
& Lactose & DCIP & 10.121 & 0.052 & 7.39 & 0.73 \\
& Cyt c & - & - & - & - \\
$\mathrm{CuCDH}$ & Cellobiose & DCIP & 0.285 & 0.189 & 18.86 & 66.18 \\
& & Cyt c & 0.175 & 0.191 & 19.06 & 108.92 \\
& Lactose & DCIP & 5.241 & 0.209 & 20.86 & 3.98 \\
& & Cyt c & 1.850 & 0.195 & 19.46 & 10.52 \\
\hline
\end{tabular}

cytochrome c, respectively. The results obtained suggested that $\mathrm{CDH}$ from $C$. unicolor strain FCL139 was unable to oxidize glucose. Strong discrimination of glucose as a substrate is a characteristic for the Basidiomycete enzymes belonging to the class I CDHs [15]. Similar values of kinetic constants were reported for other fungal cellobiose dehydrogenases [60, 61].

The influence of metal ions and substances that are potential inhibitors of different enzymes on the activity of cellobiose dehydrogenase was tested (Table 4). The activating/inhibiting effect of the analyzed substances on $\mathrm{CDH}$ was dependent on their concentration. The enzyme from $C$. unicolor is sensitive to higher concentrations of SDS and $\mathrm{CuCl}_{2}$, similarly to the protein from P. sanguineus [45]. Azide and cyanide have a slight inhibitory effect just like the CDH from Schizophyllum commune [61]. A similar activating effect in the case of divalent cations was observed by [40]. The other investigated reagents did not have any significant effect on the $\mathrm{CDH}$ activity.

\section{C. unicolor Cellobiose Dehydrogenase Structure}

The UV-vis spectra of the oxidized and reduced states of the purified $\mathrm{CDH}$ from C. unicolor indicated the presence of heme and flavin cofactors in the protein (Fig. 4). The main absorption peak of the oxidized enzyme appearing at $421 \mathrm{~nm}$ is typical for heme b, whereas the absorbance occurring in the region between 450 and $500 \mathrm{~nm}$ is mainly attributed to the FAD group [57, 62]. Reduction of the enzyme by addition of lactose resulted in appearance of peaks at 429, 532, and $562 \mathrm{~nm}$ and a decrease in absorbance at wavelengths between 450 and $500 \mathrm{~nm}$, which probably represented the reduced form of FAD [62].

The molecular weight of both fragments (CuCDH-FAD and $\mathrm{CuCDH})$ was predicted to be 58 and $97 \mathrm{kDa}$, respectively, as determined by SDS-PAGE analysis (Fig. 1). Most fungal CDHs are monomeric proteins with molecular masses between 80 and $115 \mathrm{kDa}$ [15]. Native PAGE was also performed to identify the enzymatic activities of the proteins (Fig. 1).

Chromatofocusing was used to determine the isoelectric points for $\mathrm{CuCDH}-\mathrm{FAD}$ and $\mathrm{CuCDH}$, which were detected at $\mathrm{pH} 5.50$ and 4.55, respectively. Many other intact CDHs from Basidiomycetes, such as $P$. chrysosporium, I. lacteus, T. versicolor, C. subvermispora, Phlebia lindtneri, and P. sanguineus, have acidic isoelectric points ranging from 3.0 to $5.1[15,45,57$, 63-65]. The protein containing only the FAD domain has a higher $\mathrm{pI}(5.5-6.7)$ [45, 63, 64].

Monosaccharide analysis of CDH from C. unicolor strain FCL139 showed that the sample contained mainly mannose (Man, $74.1 \%$ ). Small amounts of glucose (Glc, 6.2\%), galactose (Gal, $2.5 \%)$, and glucosamine (GlcN, $17.2 \%)$ were also present. Summarizing, the 
Table 4 Effect of metal ions and some reagents on the cellobiose dehydrogenase activity

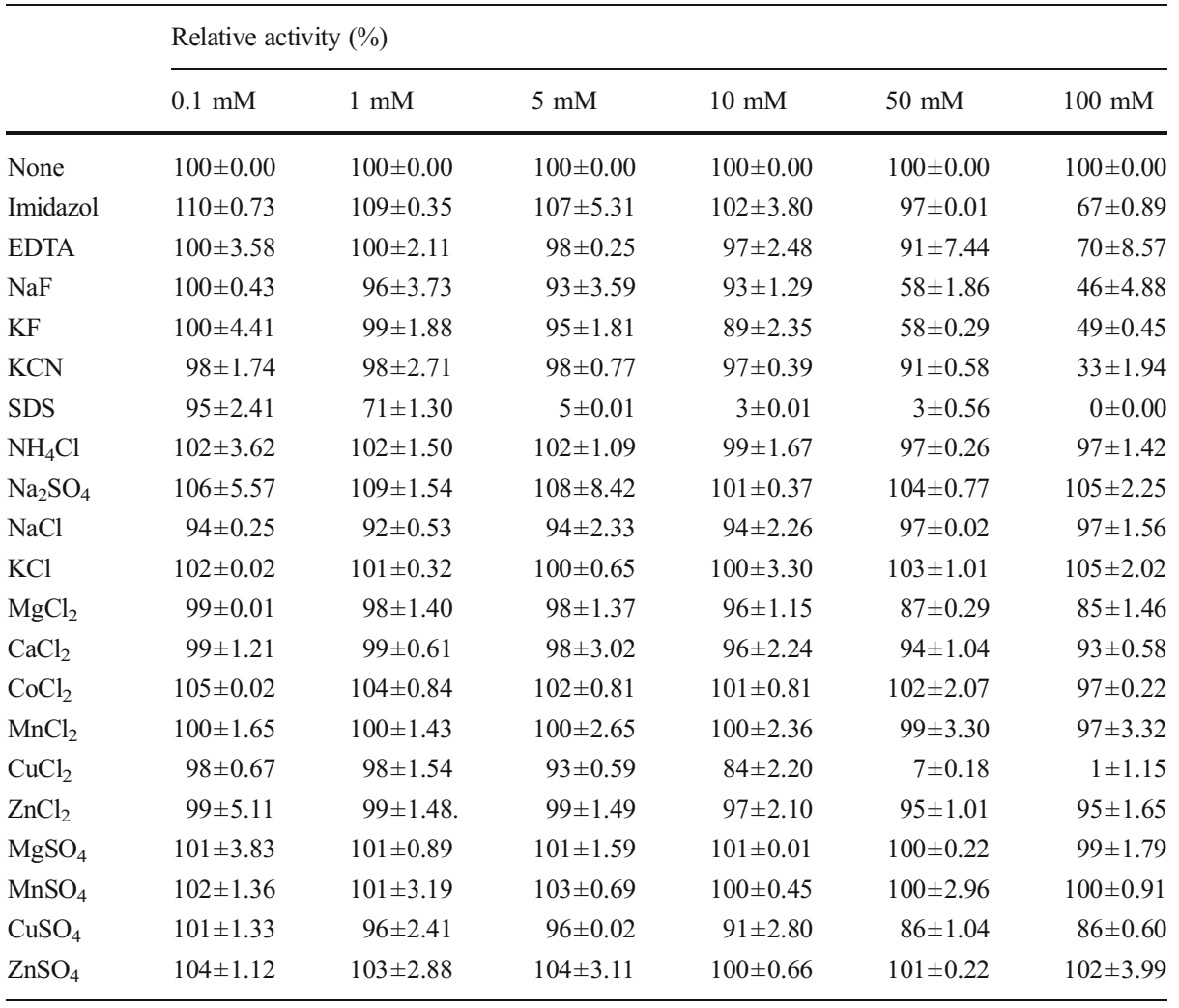

carbohydrate content of $\mathrm{CDH}$ was estimated at $8.2 \%$ using the Dubois method with mannose as a standard. The up-to-date characterized fungal cellobiose dehydrogenases comprise from 8.9 up to $19 \%$ of sugar moiety $[66,67]$.

The identity of cellobiose dehydrogenase from C. unicolor was further proved by LC-MS/ MS spectrometry analysis of the protein band observed in SDS-PAGE. The MS/MS raw data obtained were used to search against the NCBI protein database. The analyzed protein was identified when the MASCOT probability-based score $(p<0.05)$ was greater than 52 . The protein from the gel slice was identified as $\mathrm{CDH}$ from $C$. unicolor with a MASCOT score of 55,248 and sequence coverage of $67 \%$ (Fig. 5). The deduced molecular mass of C. unicolor $\mathrm{CDH}(80.9 \mathrm{kDa})$ was very similar to that determined by in silico analysis of the $\mathrm{CDH}$ amino acid sequence $(82.6 \mathrm{kDa})$.

\section{Molecular Properties of $C$. unicolor CDH}

To our knowledge, this is the first in silico analysis of the Cerrena cellobiose dehydrogenase gene. Analysis of sequenced full-length cDNA of the $c d h 1$ gene from $C$. unicolor strain FCL139 revealed one open reading frame (ORF) of $2316 \mathrm{bp}$. The deduced protein sequence of $c d h 1$ shared similarity of $72 \%$ with $P$. lindtneri cellobiose dehydrogenase (accession number AGE45679). The dendrogram obtained from the alignments of 12 cellobiose dehydrogenase amino acid sequences of Basidiomycetes and Ascomycetes showed that the putative CDH1 


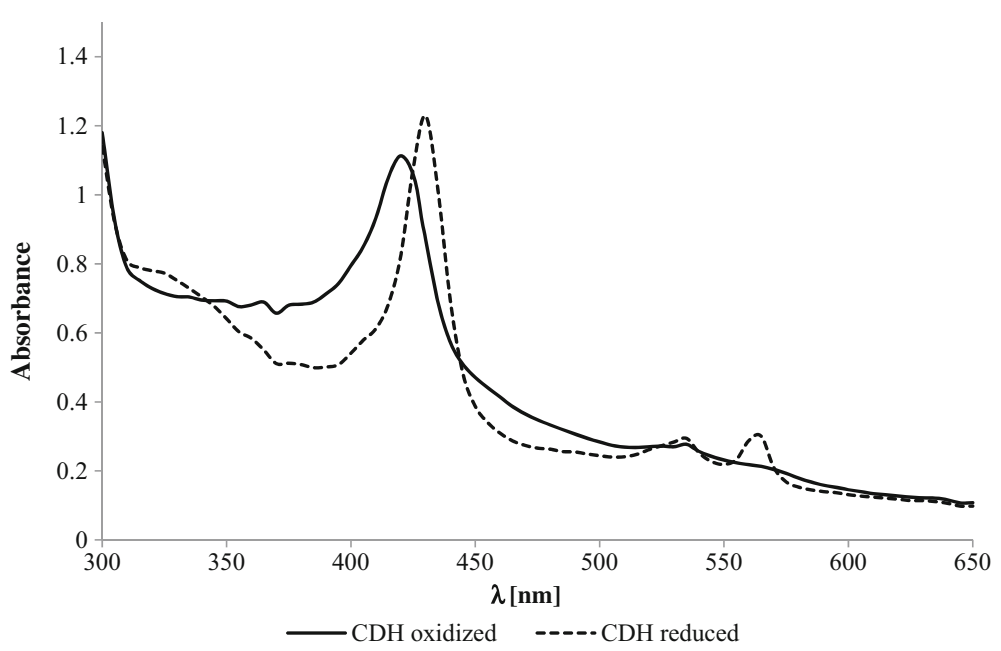

Fig. 4 UV-visible spectrum of the oxidized (line) and reduced (dashed line) forms of CDH purified from Cerrena unicolor strain 139 in $100 \mathrm{mM}$ sodium acetate buffer, $\mathrm{pH}$ 4.5. Reduction was performed with lactose. Spectra of oxidized (peak at $421 \mathrm{~nm}$ ) and reduced (peaks at 429, 532, and $562 \mathrm{~nm}$ ) CDH forms

clustered together with a similar protein from C. subvermispora (Fig. 6). Moreover, both sequences belonged to the cluster including cellobiose dehydrogenases from $T$. versicolor, $P$. lindtneri, and $P$. chrysosporium. The analyzed protein sequence (771 aa) comprised a signal sequence within the first 18 amino acids (SignalP 0845). The results obtained place the length of the C. unicolor CDH signal peptide between P. lindtneri (17 aa) and P. sanguineus (19 aa) $[45,65]$. A number of publications were produced indicating that proteolytic cleavage in the linker region resulted in the presence of the FAD domain in the culture medium $[15,68]$ even if some paper reported exceptions to this fact [57, 69]. However, our recent studies suggest that whether the linker region is digested by proteases may be a consequence of both its

$\begin{array}{rlllll}\mathbf{1} & \text { QTASSYVDPG } & \text { NGFQFVGLTD } & \text { PVHQVTYGLT } & \text { FPPLPSTGPA } & \text { PTEFIGEIVA } \\ \mathbf{5 1} & \text { PIATKWIGFA } & \text { LGGAMLHNLL } & \text { LVAWPNNGQI } & \text { VTSTRYATTY } & \text { NLPTQYDGPT } \\ \mathbf{1 0 1} & \text { LTTLPSSSVN } & \text { STHWKWVYRC } & \text { QNCTSWQGGS } & \text { LPLDSGAAVA } & \text { WAYSDVAVDQ } \\ \mathbf{1 5 1} & \text { PSNPQSTFSE } & \text { HTDFGFFGID } & \text { FSSAHNPNYE } & \text { SYLSGNAPAP } & \text { PTSVPPTGPS } \\ \mathbf{2 0 1} & \text { TTTQPTGPTI } & \text { QPTPYDYIVV } & \text { GAGPGGIIAA } & \text { DRISEAGKKV } & \text { LLIERGGPST } \\ \mathbf{2 5 1} & \text { AETGGTYYAP } & \text { WTADKKLTKF } & \text { DVPGLFESMF } & \text { SDSNPWYWCK } & \text { DITVFAGCLL } \\ \mathbf{3 0 1} & \text { GGGTSINGAL } & \text { YWYPTTSDFS } & \text { TAAGWPSSWT } & \text { NHGPYTNKLK } & \text { ARLPSTDHPS } \\ \mathbf{3 5 1} & \text { MDGKRYLTQA } & \text { YDVAWQMLKN } & \text { QGYNQITLND } & \text { NPDFKDHAFG } & \text { YSAFDFVDGK } \\ \mathbf{4 0 1} & \text { RGGPVASYLR } & \text { TAKARSNFAY } & \text { MDYTIVSNVV } & \text { RNGSKITGVQ } & \text { TNNTQIGGNG } \\ \mathbf{4 5 1} & \text { IIPLNPNGRV } & \text { ILSAGSFGSP } & \text { RILFQSGIGP } & \text { SDMLTLVQGN } & \text { ADAAKKLPPS } \\ \mathbf{5 0 1} & \text { NQFINLPVGM } & \text { NVQDNPSINL } & \text { VFTHPSIDAY } & \text { ENWADVWSKP } & \text { RPADAQKYLN } \\ \mathbf{5 5 1} & \text { GFDGVFAGAS } & \text { PKANFWRAYG } & \text { AADGITRYAQ } & \text { GTVRPGAASI } & \text { NTTLPYNASN } \\ \mathbf{6 0 1} & \text { IFTITMYLST } & \text { GITSRGRVGI } & \text { DAALRARPLV } & \text { NPWFADPTDK } & \text { TVLVKALKDV } \\ \mathbf{6 5 1} & \text { ISTMDQVPDL } & \text { TMITPDVQMT } & \text { IDQYVDAYDP } & \text { SSMNSNHWVG } & \text { SNKIGTSPST } \\ \mathbf{7 0 1} & \text { AVVDENTKVF } & \text { NTDNLFIVDA } & \text { SIIPSLPTGN } & \text { PHGMLMSAAE } & \text { QAVAKILALS }\end{array}$

Fig. 5 Complete sequence of $C$. unicolor $\mathrm{CDH}$ (AGS09133) with matched peptides in bold (sequence coverage: $67 \%)$ 
vulnerability and higher proteolytic activities in the cellulose-based medium. It is probable that among many proteases produced by white rot fungi only, one fraction is capable of cleaving cellobiose dehydrogenase. The problem should be addressed in detail in future studies comprising various techniques and fungal species.

Within the putative protein sequence of $C$. unicolor $\mathrm{CDH}$, conserved domains typical for fungal cellobiose dehydrogenase were found at positions 23 to 189 aa (heme-binding cytochrome domain) from 206 to 231 aa (the linker region) and 233 to 769 aa (choline and flavoproteins domain). Moukha et al. [70] and Harreither et al. [19] proposed conserved residues constituting a putative cellulose binding module in basidiomycetous cellobiose dehydrogenases, which was also found in P. sanguineus $\mathrm{CDH}$ [45]. A similar module was detected in C. unicolor CDH in positions Tyr-275, Trp-279, Phe-288, Phe-294, Phe-298, Trp304, Trp-306, and Phe-313. Analysis of $N$-glycosylation sites (Asn-X-Thr/Ser) showed glycosylation points at positions Asn-128, Asn-140, Asn-450, Asn-533, and Asn-615. In comparison with the $P$. sanguineus cellobiose dehydrogenase [45], only ten $O$-glycosylation sites were found within the linker region.

The complete $C$. unicolor $\mathrm{CDH}$ gene $(3038 \mathrm{bp})$ was amplified by PCR using a genomic DNA as a template and primers designed on the basis of the nucleotide sequence of the $c d h 1$ cDNA, as described in the "Materials and Methods" section. The position of putative introns within the cellobiose dehydrogenase gene was determined by comparison of the genomic DNA and cDNA sequences. Eleven introns were found, ranging in size from 53 to 92 bp and all of them fell into the GT-AG rule [71]. Similarly to P. sanguineus, the cellobiose dehydrogenase gene contains fewer introns, likewise those of $P$. cinnabarinus [70] or P. chrysosporium [72]; however, the last intron is exceptionally long (92 bp).

\section{Antioxidant Activity Assays}

Fungi are producers of a large number of bioactive compounds with antioxidant properties. In the earlier studies, we have shown strong antioxidant capability of the fungal CDH from $P$. sanguineus [45]. Determination of the antioxidant activity of the newly isolated cellobiose dehydrogenase from $C$. unicolor is important for future research on its biotechnological

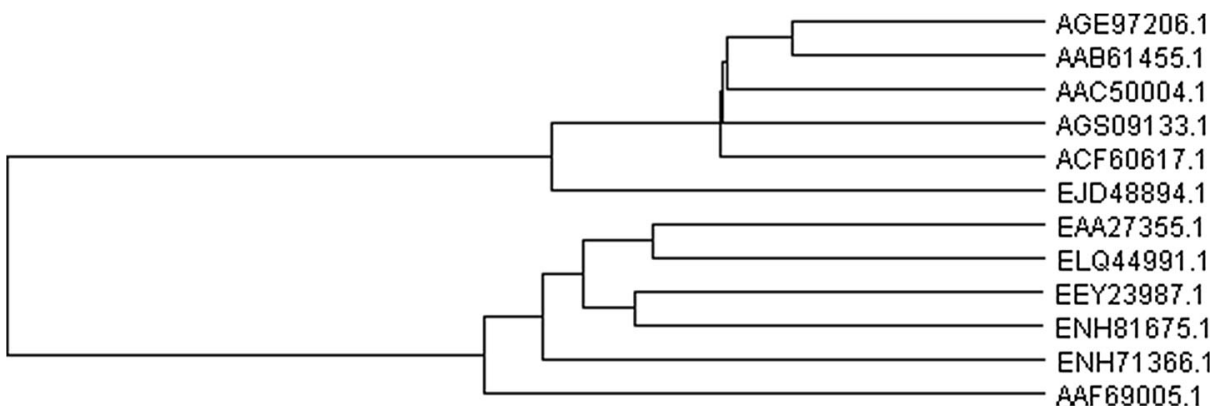

Fig. 6 Unrooted UPGMA-based phylogenetic trees constructed with 12 protein sequences. The dendrogram of several cellobiose dehydrogenases from fungi. AGE97206- Phlebia lindtneri, AAB61455.1- Phanerochaete chrysosporium, AAC50004.1- Trametes versicolor, AGS09133-Cerrena unicolor, ACF60617.1-Ceriporiopsis subvermispora, EJD48894- Auricularia delicata TFB-10046 SS5, EAA27355.1- Neurospora crassa OR74A, ELQ44991.1- Magnaporthe oryzae Y34, EEY23987.1- Verticillium alfalfae VaMs.102, ENH81675.1Colletotrichum orbiculare MAFF 240422, ENH71366.1- Fusarium oxysporum $f$. sp. cubense race 1, AAF69005.1- Humicola insolens 


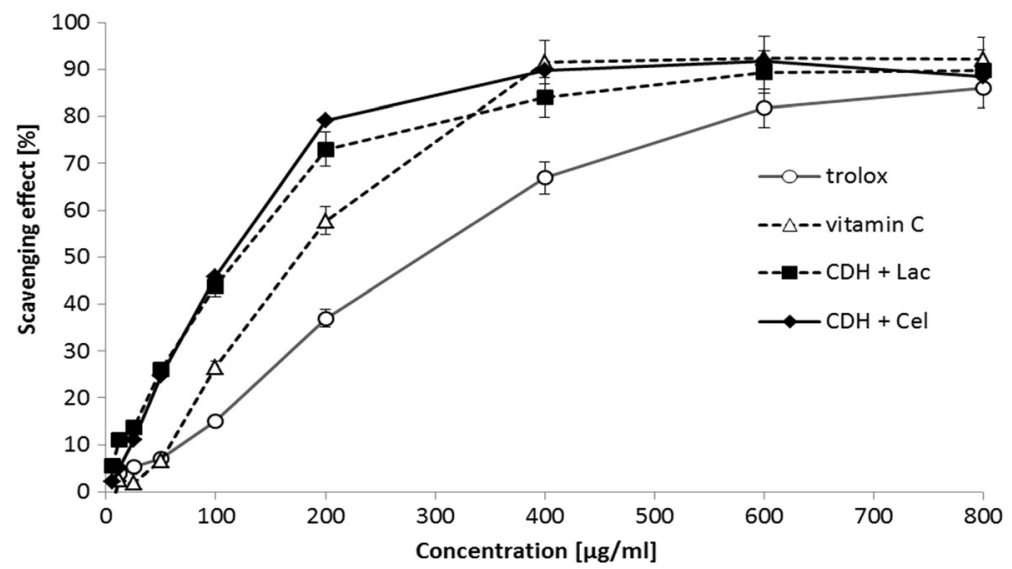

Fig. 7 Comparison of the antioxidant properties of cellobiose dehydrogenase with and without substrates (cellobiose and lactose) from Cerrena unicolor determined by the ABTS method. Values represent the mean \pm SD of triplicate samples

potential. We applied two different methods commonly used to estimate the antioxidant potential: the DPPH and ABTS method. The obtained results showed that intact CDH without substrates have no antioxidant activity. Evaluation of antioxidant activity of the intact CDH with substrates (cellobiose and lactose) is shown in Fig. 7 (ABTS method) and Fig. 8 (DPPH method). Antioxidant activity measured by DPPH showed the similar effects as the ABTS method if the substrate was the electron donor. The scavenging abilities of $\mathrm{CDH}$ with lactose and cellobiose at the concentration range of $6.25-800 \mu \mathrm{g} / \mathrm{ml}$ were estimated at $89.3-91.6 \%$ for ABTS and $81.8-82.1 \%$ for the DPPH method, respectively. The $\mathrm{EC}_{50}$ values of $\mathrm{CDH}$, i.e., the concentration of the enzyme necessary to decrease the initial concentration of DPPH and ABTS by $50 \%$, was calculated and expressed in Table 5 . The lowest values of $\mathrm{EC}_{50}$ were observed for the DPPH radical scavenging method, i.e., $39.8 \mu \mathrm{g} / \mathrm{ml}$ for $\mathrm{CDH}$ with lactose and

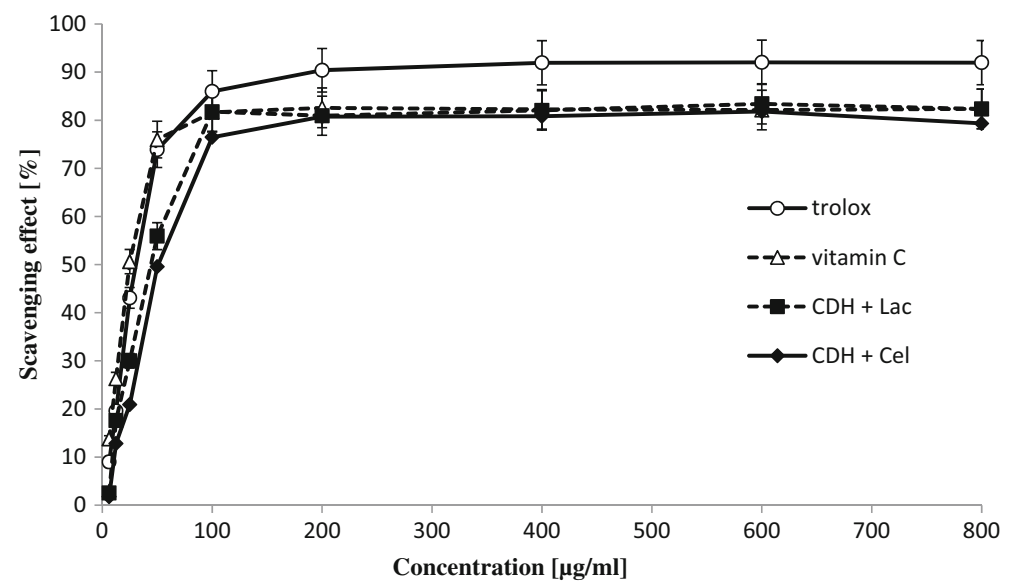

Fig. 8 Comparison of the antioxidant properties of cellobiose dehydrogenase with and without substrates (cellobiose and lactose) from Cerrena unicolor determined by the DPPH method. Values represent the mean \pm SD of triplicate samples 
Table $5 \mathrm{EC}_{50}$ values (effective concentration at which the radicals present in the investigated samples were scavenged by $50 \%$; the antioxidant activity was $50 \%$ ) of $\mathrm{CDH}$ isolated from C. unicolor submerged cultures in comparison to Trolox and vitamin $\mathrm{C}$

\begin{tabular}{lcc}
\hline & \multicolumn{2}{c}{ EC50 $(\mu \mathrm{g} / \mathrm{mL})$} \\
\cline { 2 - 3 } & ABTS radical scavenging & DPPH radical scavenging \\
\hline Trolox & $251.6 \pm 7.86$ & $28.4 \pm 0.72$ \\
Vitamin C & $151.3 \pm 5.14$ & $25.1 \pm 0.61$ \\
$\mathrm{CDH}$ & - & - \\
$\mathrm{CDH}+$ lactose & $103.7 \pm 3.76$ & $39.8 \pm 1.42$ \\
$\mathrm{CDH}+$ cellobiose & $93.0 \pm 2.53$ & $48.5 \pm 1.56$ \\
\hline
\end{tabular}

All results are expressed as mean \pm SD from three experiments $(n=3)$. Values within the column and the row for investigated samples are significantly different $(P \leq 0.05)$

$48.5 \mu \mathrm{g} / \mathrm{ml}$ for $\mathrm{CDH}$ with cellobiose. The $\mathrm{EC}_{50}$ values for the ABTS method used for testing the $\mathrm{CDH}$ antioxidative properties were 103.7 and $93 \mu \mathrm{g} / \mathrm{ml}$, respectively. All the results obtained indicate strong redox potential of the $\mathrm{CDH}$ enzyme only in the presence of lactose and cellobiose substrates. Therefore, it would be interesting to investigate whether $C$. unicolor $\mathrm{CDH}$ may be applied as an antimicrobial agent, as recently described for Myriococcum thermophilum cellobiose dehydrogenase [73].

C. unicolor strain FCL139 was proven to produce not only biotechnologically important laccase but also cellobiose dehydrogenase with interesting features as well. Given the size and gene content of the available $C$. unicolor genome, its $\mathrm{CDH}$ is only part of the wood degrading machinery and it would be interesting to characterize in detail the abilities of this white rot fungus of decompose lignocellulose. The recent explosion of interest in cellobiose dehydrogenase, which was proven to act in concert with LPMO (lytic polysaccharide monooxygenase) in cellulose breakdown and was successfully applied in different biotechnological areas, encourages scientists all over the world to search for new $\mathrm{CDH}$ with exceptional features. By applying high throughput techniques, new insight into the wood decomposition is possible. In consequence, the acquired knowledge will contribute to accelerating the application of the discovered and characterized enzymes in new biotechnological areas.

Acknowledgments This research was supported by the grant Preludium (2011/01/N/NZ1/03458) from the National Science Centre in Poland and the research program BS/UMCS.

Open Access This article is distributed under the terms of the Creative Commons Attribution 4.0 International License (http://creativecommons.org/licenses/by/4.0/), which permits unrestricted use, distribution, and reproduction in any medium, provided you give appropriate credit to the original author(s) and the source, provide a link to the Creative Commons license, and indicate if changes were made.

\section{References}

1. Kellner, H., Zak, D. R., \& Vandenbol, M. (2010). Correction: fungi unearthed: transcripts encoding lignocellulolytic and chitinolytic enzymes in forest soil. PLoS One, 5, 1-7.

2. Novotný, Č., Cajthaml, T., Svobodova, K., Šušla, M., \& Šašek, V. (2009). Irpex lacteus, a white-rot fungus with biotechnological potential —review. Folia Microbiologica, 54, 375-390. 
3. Leonowicz, A., Matuszewska, A., Luterek, J., Ziegenhagen, D., Wojtas-Wasilewska, M., Cho, N. S., Hofrichter, M., \& Rogalski, J. (1999). Biodegradation of lignin by white rot fungi. Fungal Genetics and Biology, 27, 175-185.

4. Patel, Y., Naraian, R., \& Singh, V. (2012). Medicinal properties of Pleurotus species (Oyster Mushroom): a review. World, 3, 01-12.

5. Reynolds, N. P., Janusz, S., Escalante-Marun, M., Timney, J., Ducker, R. E., Olsen, J. D., Otto, C., Subramaniam, V., Leggett, G. J., \& Hunter, C. N. (2007). Directed formation of micro- and nanoscale patterns of functional light-harvesting LH2 complexes. Journal of the American Chemical Society, 129, $14625-14631$.

6. Hibi, M., Hatahira, S., Nakatani, M., Yokozeki, K., Shimizu, S., \& Ogawa, J. (2012). Extracellular oxidases of Cerrena sp. complementarily functioning in artificial dye decolorization including laccase, manganese peroxidase, and novel versatile peroxidases. Biocatalysis Agricultural Biotechnology, 1, 220-225.

7. Belova, O. V., Lisov, A. V., Vinokurova, N. G., Kostenevich, A. A., Sapunova, L. I., Lobanok, A. G., \& Leontievsky, A. A. (2014). Xylanase and cellulase of fungus Cerrena unicolor VKM F-3196: production, properties, and applications for the saccharification of plant material. Applied Biochemistry and Microbiology, 50, 148-153.

8. Enebak, S. A., \& Blanchette, R. A. (1989). Canker formation and decay in sugar maple and paper birch infected by Cerrena unicolor. Canadian Journal of Forest Research, 19, 225-231.

9. Yamac, M., Zeytinoglu, M., Kanbak, G., Bayramoglu, G., \& Senturk, H. (2009). Hypoglycemic effect of crude exopolysaccharides produced by Cerrena unicolor, Coprinus comatus, and Lenzites betulina isolates in streptozotocin-induced diabetic rats. Pharmaceutical Biology, 47, 168-174.

10. Jaszek, M., Osinska-Jaroszuk, M., Janusz, G., Matuszewska, A., Stefaniuk, D., Sulej, J., Polak, J., Ruminowicz, M., Grzywnowicz, K., \& Jarosz-Wilkolazka, A. (2013). New bioactive fungal molecules with high antioxidant and antimicrobial capacity isolated from Cerrena unicolor idiophasic cultures. BioMed Research International, 2013, 497492.

11. Westermark, U., \& Eriksson, K.-E. (1974). Cellobiose: quinone oxidoreductase, a new wood-degrading enzyme from white-rot fungi. Acta Chemica Scandinavica, Series B: Organic Chemistry and Biochemistry, $28,209-214$.

12. Westermark, U., \& Eriksson, K. E. (1975). Purification and properties of cellobiose: quinone oxidoreductase from Sporotrichum pulverulentum. Acta Chemica Scandinavica, Series B: Organic Chemistry and Biochemistry, 29, 419-424.

13. Staudigl, P., Krondorfer, I., Haltrich, D., \& Peterbauer, C. K. (2013). Pyranose dehydrogenase from Agaricus campestris and Agaricus xanthoderma: characterization and applications in carbohydrate conversions. Biomolecules, 3, 535-552.

14. Hallberg, B. M., Bergfors, T., Bäckbro, K., Pettersson, G., Henriksson, G., \& Divne, C. (2000). A new scaffold for binding haem in the cytochrome domain of the extracellular flavocytochrome cellobiose dehydrogenase. Structure, 8, 79-88.

15. Zamocky, M., Ludwig, R., Peterbauer, C., Hallberg, B. M., Divne, C., Nicholls, P., \& Haltrich, D. (2006). Cellobiose dehydrogenase - a flavocytochrome from wood-degrading, phytopathogenic and saprotropic fungi. Current Protein and Peptide Science, 7, 255-280.

16. Nyanhongo, G. S., Gubitz, G., Sukyai, P., Leitner, C., Haltrich, D., \& Ludwig, R. (2007). Oxidoreductases from Trametes spp. in biotechnology: a wealth of catalytic activity. Food Technology and Biotechnology, 45, 250 .

17. Mowat, C. G., Gazur, B., Campbell, L. P., \& Chapman, S. K. (2010). Flavin-containing heme enzymes. Archives of Biochemistry and Biophysics, 493, 37-52.

18. Turbe-Doan, A., Arfi, Y., Record, E., Estrada-Alvarado, I., \& Levasseur, A. (2013). Heterologous production of cellobiose dehydrogenases from the basidiomycete Coprinopsis cinerea and the ascomycete Podospora anserina and their effect on saccharification of wheat straw. Applied Microbiology and Biotechnology, 97, 4873-4885.

19. Harreither, W., Sygmund, C., Augustin, M., Narciso, M., Rabinovich, M. L., Gorton, L., Haltrich, D., \& Ludwig, R. (2011). Catalytic properties and classification of cellobiose dehydrogenases from ascomycetes. Applied and Environmental Microbiology, 77, 1804-1815.

20. Kremer, S., \& Wood, P. (1992). Production of Fenton's reagent by cellobiose oxidase from cellulolytic cultures of Phanerochaete chrysosporium. European Journal of Biochemistry/FEBS, 208, 807-814.

21. Phillips, C. M., Beeson, W. T., IV, Cate, J. H., \& Marletta, M. A. (2011). Cellobiose dehydrogenase and a copper-dependent polysaccharide monooxygenase potentiate cellulose degradation by Neurospora crassa. ACS Chemical Biology, 6, 1399-1406.

22. Sygmund, C., Kracher, D., Scheiblbrandner, S., Zahma, K., Felice, A. K., Harreither, W., Kittl, R., \& Ludwig, R. (2012). Characterization of the two Neurospora crassa cellobiose dehydrogenases and 
their connection to oxidative cellulose degradation. Applied and Environmental Microbiology, 78, 6161-6171.

23. Bey, M., Zhou, S., Poidevin, L., Henrissat, B., Coutinho, P. M., Berrin, J.-G., \& Sigoillot, J.-C. (2013). Cello-oligosaccharide oxidation reveals differences between two lytic polysaccharide monooxygenases (family GH61) from Podospora anserina. Applied and Environmental Microbiology, 79, 488-496.

24. Ludwig, R., Ozga, M., Zámocky, M., Peterbauer, C., Kulbe, K. D., \& Haltrich, D. (2004). Continuous enzymatic regeneration of electron acceptors used by flavoenzymes: cellobiose dehydrogenase-catalyzed production of lactobionic acid as an example. Biocatalysis and Biotransformation, 22, 97-104.

25. Hilden, L., \& Johansson, G. (2004). Recent developments on cellulases and carbohydrate-binding modules with cellulose affinity. Biotechnology Letters, 26, 1683-1693.

26. Harreither, W., Coman, V., Ludwig, R., Haltrich, D., \& Gorton, L. (2007). Investigation of graphite electrodes modified with cellobiose dehydrogenase from the ascomycete Myriococcum thermophilum. Electroanalysis, 19, 172-180.

27. Safina, G., Ludwig, R., \& Gorton, L. (2010). A simple and sensitive method for lactose detection based on direct electron transfer between immobilised cellobiose dehydrogenase and screen-printed carbon electrodes. Electrochimica Acta, 55, 7690-7695.

28. Stoica, L., Ludwig, R., Haltrich, D., \& Gorton, L. (2006). Third-generation biosensor for lactose based on newly discovered cellobiose dehydrogenase. Analytical Chemistry, 78, 393-398.

29. Nistor, C., Rose, A., Farré, M., Stoica, L., Wollenberger, U., Ruzgas, T., Pfeiffer, D., Barceló, D., Gorton, L., \& Emnéus, J. (2002). In-field monitoring of cleaning efficiency in waste water treatment plants using two phenol-sensitive biosensors. Analytica Chimica Acta, 456, 3-17.

30. Rabinovich, M. L., Vasil'chenko, L. G., Karapetyan, K. N., Shumakovich, G. P., Yershevich, O. P., Ludwig, R., Haltrich, D., Hadar, Y., Kozlov, Y. P., \& Yaropolov, A. I. (2007). Application of cellulose-based selfassembled tri-enzyme system in a pseudo-reagent-less biosensor for biogenic catecholamine detection. Biotechnology Journal, 2, 546-558.

31. Ludwig, R., Ortiz, R., Schulz, C., Harreither, W., Sygmund, C., \& Gorton, L. (2013). Cellobiose dehydrogenase modified electrodes: advances by materials science and biochemical engineering. Analytical and Bioanalytical Chemistry, 405, 3637-3658.

32. Nyanhongo, G. S., Sygmund, C., Ludwig, R., Prasetyo, E. N., \& Guebitz, G. M. (2013). Synthesis of multifunctional bioresponsive polymers for the management of chronic wounds. Journal of Biomedical Materials Research Part B: Applied Biomaterials, 101, 882-891.

33. Nyanhongo, G. S., Sygmund, C., Ludwig, R., Prasetyo, E. N., \& Guebitz, G. M. (2013). An antioxidant regenerating system for continuous quenching of free radicals in chronic wounds. European Journal of Pharmaceutics and Biopharmaceutics, 83, 396-404.

34. Lindeberg, G., \& Holm, G. (1952). Occurrence of tyrosinase and laccase in fruit bodies and mycelia of some Hymenomycetes. Physiologia Plantarum, 5, 100-114.

35. Fang, J., Huang, F., \& Gao, P. J. (1999). Optimization of cellobiose dehydrogenase production by Schizophyllum commune and effect of the enzyme on kraft pulp bleaching by ligninases. Process Biochemistry (Amsterdam, Netherlands), 34, 957-961.

36. Rogalski, J., \& Dawidowicz, A. (1989). Controlled porous glass (CPG) with reactive epoxy groups as support for affinity chromatography I. Optimization of CPG modification and the binding of glucose with modified surface. Acta Biotechnologica, 9, 275-283.

37. Dawidowicz, A., \& Rogalski, J. (1988). Sposób otrzymywania nośników z powierzchnią modyfikowaną alkoksysilanami. (ed Maria Curie-Sklodowska University, L., Poland). Poland.

38. Rogalski, J. and Dawidowicz, A. (1990) The preparation of supports with the reactive epoxy groups. (ed Maria Curie-Sklodowska University, L., Poland). Poland.

39. Kordan, W., Malinowska, A., Lecewicz, M., Wysocki, P., Fraser, L., \& Strzezek, J. (2007). The structure of platelet-activating factor acetylhydrolase (PAF-AH) isolated from boar seminal plasma and examined using mass spectrometry. Animal Science Papers and Reports, 25, 289-295.

40. Kracher, D., Zahma, K., Schulz, C., Sygmund, C., Gorton, L. and Ludwig, R. (2015). Interdomain electron transfer in cellobiose dehydrogenase: modulation by $\mathrm{pH}$ and divalent cations. FEBS J.

41. Laemmli, U. K. (1970). Cleavage of structural proteins during the assembly of the head of bacteriophage T4. Nature, 227, 680-685.

42. Walker, J. M. (2002). The protein protocols handbook (2nd ed.). Totowa: Humana Press.

43. Sawardeker, J. S., Sloneker, J., \& Jeanes, A. (1965). Quantitative determination of monosaccharides as their alditol acetates by gas liquid chromatography. Analytical Chemistry, 37, 1602-1604.

44. Dubois, M., Gilles, K. A., Hamilton, J. K., Rebers, P., \& Smith, F. (1956). Colorimetric method for determination of sugars and related substances. Analytical Chemistry, 28, 350-356. 
45. Sulej, J., Janusz, G., Osinska-Jaroszuk, M., Malek, P., Mazur, A., Komaniecka, I., Choma, A., \& Rogalski, J. (2013). Characterization of cellobiose dehydrogenase and its FAD-domain from the ligninolytic basidiomycete Pycnoporus sanguineus. Enzyme and Microbial Technology, 53, 427-437.

46. Paduch, R., Matysik, G., Wojciak-Kosior, M., Kandefer-Szerszen, M., Skalska-Kaminska, A., NowakKryska, M., \& Niedziela, P. (2008). Lamium album extracts express free radical scavenging and cytotoxic activities. Polish Journal of Environmental Studies, 17, 569-580.

47. Re, R., Pellegrini, N., Proteggente, A., Pannala, A., Yang, M., \& Rice-Evans, C. (1999). Antioxidant activity applying an improved ABTS radical cation decolorization assay. Free Radical Biology and Medicine, 26, 1231-1237.

48. Sambrook, J., \& Russell, D.W. (2006). The condensed protocols from molecular cloning: a laboratory manual. ed. Cold Spring Harbor Laboratory Press, Cold Spring Harbor, N.Y.

49. Borges, M. J., Azevedo, M. O., Bonatelli, J. R., Felipe, M. S. S., \& Astolfi-Filho, S. (1990). A practical method for the preparation of total DNA from filamentous fungi. Fungal General Newsletter, 10, 11.

50. Thompson JD, Higgins DG, Gibson TJ. Clustal-W improving the sensitivity of progressive multiple sequence alignment through sequence weighting, position-specific gap penaltiesand weight matrix choice. Nucleic Acids Res 1994;22:4673-4680

51. Page RDM. TreeView: An application to display phylogenetic trees on personal computers. Computer Applications in the Biosciences 1996;12:357-358

52. Steentoft, C., Vakhrushev, S. Y., Joshi, H. J., Kong, Y., Vester-Christensen, M. B., Schjoldager, K. T., Lavrsen, K., Dabelsteen, S., Pedersen, N. B., Marcos-Silva, L., Gupta, R., Bennett, E. P., Mandel, U., Brunak, S., Wandall, H. H., Levery, S. B., \& Clausen, H. (2013). Precision mapping of the human OGalNAc glycoproteome through SimpleCell technology. The EMBO Journal, 32, 1478-1488.

53. Geer, L. Y., Domrachev, M., Lipman, D. J., \& Bryant, S. H. (2002). CDART: protein homology by domain architecture. Genetical Research, 12, 1619-1623.

54. Hai, P. Q., Nozaki, K., Amano, Y., \& Kanda, T. (2000). Purification and characterization of cellobiose dehydrogenase from Irpex lacteus and its adsorption on cellulose. Journal of Applied Glycoscience, 47, 311318.

55. Roy, B. P., Dumonceaux, T., Koukoulas, A. A., \& Archibald, F. S. (1996). Purification and characterization of cellobiose dehydrogenases from the white rot fungus Trametes versicolor. Applied and Environmental Microbiology, 62, 4417-4427.

56. Igarashi, K., Verhagen, M. F., Samejima, M., Schulein, M., Eriksson, K. E., \& Nishino, T. (1999). Cellobiose dehydrogenase from the fungi Phanerochaete chrysosporium and Humicola insolens. A flavohemoprotein from Humicola insolens contains 6-hydroxy-FAD as the dominant active cofactor. Journal of Biological Chemistry, 274, 3338-3344.

57. Harreither, W., Sygmund, C., Dunhofen, E., Vicuna, R., Haltrich, D., \& Ludwig, R. (2009). Cellobiose dehydrogenase from the ligninolytic basidiomycete Ceriporiopsis subvermispora. Applied and Environmental Microbiology, 75, 2750-2757.

58. Ludwig, R., \& Haltrich, D. (2002). Cellobiose dehydrogenase production by Sclerotium species pathogenic to plants. Letters in Applied Microbiology, 35, 261-266.

59. Sigoillot, C., Lomascolo, A., Record, E., Robert, J. L., Asther, M., \& Sigoillot, J. C. (2002). Lignocellulolytic and hemicellulolytic system of Pycnoporus cinnabarinus: isolation and characterization of a cellobiose dehydrogenase and a new xylanase. Enzyme and Microbial Technology, 31, 876-883.

60. Ludwig, R., Salamon, A., Varga, J., Zamocky, M., Peterbauer, C., Kulbe, K., \& Haltrich, D. (2004). Characterisation of cellobiose dehydrogenases from the white-rot fungi Trametes pubescens and Trametes villosa. Applied Microbiology and Biotechnology, 64, 213-222.

61. Fang, J., Liu, W., \& Gao, P. (1998). Cellobiose dehydrogenase from Schizophyllum commune: purification and study of some catalytic, inactivation, and cellulose-binding properties. Archives of Biochemistry and Biophysics, 353, 37-46.

62. Baminger, U., Subramaniam, S. S., Renganathan, V., \& Haltrich, D. (2001). Purification and characterization of cellobiose dehydrogenase from the plant pathogen Sclerotium (Athelia) rolfsii. Applied and Environmental Microbiology, 67, 1766-1774.

63. Mikiashvili, N., Elisashvili, V., Worku, M., Davitashvili, E., \& Isikhuemhen, O. S. (2009). Purification and characterization of a lectin isolated from the submerged cultivated mycelium of grey polypore Cerrena unicolor (Bull.) Murrill (Aphyllophoromycetideae). International Journal of Medicinal Mushrooms, 11, 6168.

64. Barron, G.L. (1999). Mushrooms of Northeast North America: Midwest to New England. ed. Lone Pine Pub.

65. Sulej, J., Janusz, G., Mazur, A., Zuber, K., Zebracka, A., \& Rogalski, J. (2013). Cellobiose dehydrogenase from the ligninolytic basidiomycete Phlebia lindtneri. Process Biochemistry, 48, 1715-1723. 
66. Sadana, J. C., \& Patil, R. V. (1985). The purification and properties of cellobiose dehydrogenase from Sclerotium rolfsii and its role in cellulolysis. Journal of General Microbiology, 131, 1917-1923.

67. Stapleton, P. C., O’Brien, M. M., O’Callaghan, J., \& Dobson, A. D. W. (2004). Molecular cloning of the cellobiose dehydrogenase gene from Trametes versicolor and expression in Pichia pastoris. Enzyme and Microbial Technology, 34, 55-63.

68. Cameron, M. D., \& Aust, S. D. (2001). Cellobiose dehydrogenase-an extracellular fungal flavocytochrome. Enzyme and Microbial Technology, 28, 129-138.

69. Schou, C., Christensen, M. H., \& Schulein, M. (1998). Characterization of a cellobiose dehydrogenase from Humicola insolens. Biochemistry Journal, 330(Pt 1), 565-571.

70. Moukha, S. M., Dumonceaux, T. J., Record, E., \& Archibald, F. S. (1999). Cloning and analysis of Pycnoporus cinnabarinus cellobiose dehydrogenase. Gene, 234, 23-33.

71. Padgett, R. A., Konarska, M. M., Grabowski, P. J., Hardy, S. F., \& Sharp, P. A. (1984). Lariat RNA's as intermediates and products in the splicing of messenger RNA precursors. Science, 225, 898-903.

72. Li, B., Nagalla, S. R., \& Renganathan, V. (1997). Cellobiose dehydrogenase from Phanerochaete chrysosporium is encoded by two allelic variants. Applied and Environmental Microbiology, 63, 796-799.

73. Thallinger, B., Argirova, M., Lesseva, M., Ludwig, R., Sygmund, C., Schlick, A., Nyanhongo, G.S., Guebitz, G.M. (2014). Preventing microbial colonisation of catheters: antimicrobial and antibiofilm activities of cellobiose dehydrogenase. Int. J. Antimicrob. Agents. 